ENTREPRENEURSHIP AND SUSTAINABILITY ISSUES

ISSN 2345-0282 (online) http://jssidoi.org/jesi/ 2020 Volume 8 Number 1 (September)

http://doi.org/10.9770/jesi.2020.8.1(60)

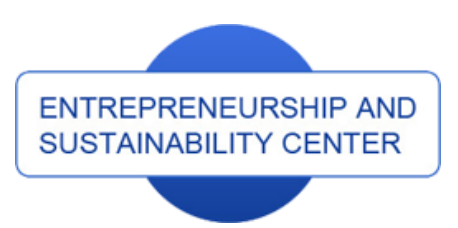

Publisher

http://jssidoi.org/esc/home

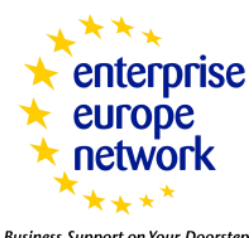

Business Support on Your Doorstep

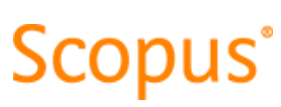

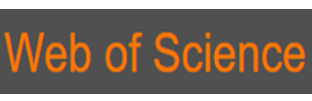

1) Clarivate

Analytics

\title{
MEDICATION MARKET PERFORMANCE ANALYSIS WITH HELP OF ANALYTIC HIERARCHY PROCESSING
}

\author{
Vladislav Trubnikov ${ }^{1}$, Artur Meynkhard ${ }^{2}$, Kristina Shvandar ${ }^{3}$, Oleg Litvishko ${ }^{4}$, Valery Titov ${ }^{4}$ \\ ${ }^{1}$ Worcester Polytechnic Institute, Worcester, Institute Rd, 100, Worcester, MA 01609, United States \\ ${ }^{2}$ Financial University under the Government of the Russian Federation, Leningradsky Ave, 49, 125167, Moscow, Russian \\ Federation \\ ${ }^{3}$ Financial Research Institute of Ministry of Finance of the Russian Federation, Nastasyinsky Lane, 3, 2, 127006, Moscow, \\ Russian Federation \\ ${ }^{4}$ Plekhanov Russian University of Economics, Stremyanny Lane, 36, 117997, Moscow, Russian Federation \\ E-mail: ${ }^{1}$ uyeh.daniel@yahoo.com; ${ }^{2}$ meynkhard@yandex.ru
}

Received 18 February 2020; accepted 26 June 2020; published 30 September 2020

\begin{abstract}
This study proposes the concept of Analytic Hierarchy Processing (AHP) on the market of active substances used in treatment of HIV and checks the control factors and criteria interconnection and implements Random Forest forecasting model. The new method must help to improve the management decision-making process in the fields of healthcare government budget planning. It has become a prime concern for understanding and comparing of publicly available information with internal market data and the consequences of companies and government's actions in choosing the best approach for correct construction of to reduce HIV incidence in Russia. The paper develops the forecasting model of one of the parameters, which has a substantial role in decision-making process. The medication market data in this study represents the cumulative daily concluded contracts, used in treatment of HIV in Russia, the level of HIV incidence (yearly) and federal budget on healthcare (yearly). The proposed approach have more than $82 \%$ average accuracy at predicting the sum of medication contract prices at the 3-year time period. The received figures are effective in predicting the factors behavior in future. It can be used for improved modulation of AHP and consequently, the overall accuracy of the model structure.
\end{abstract}

Keywords: medical contract prices analysis; multy criteria decision making; machine learning approach; innovations; healthcare management; HIV; Russia

Reference to this paper should be made as follows: Trubnikov, V., Meynkhard, A., Shvandar, K., Litvishko, O., Titov, V. 2020. Medication market performance analysis with help of Analytic Hierarchy Processing. Entrepreneurship and sustainability Issues, 8(1), 899-916. http://doi.org/10.9770/jesi.2020.8.1(60)

JEL Classification: D40, I11, I18 


\section{ENTREPRENEURSHIP AND SUSTAINABILITY ISSUES}

ISSN 2345-0282 (online) http://jssidoi.org/jesi/

2020 Volume 7 Number 5 (September)

http://doi.org/10.9770/jesi.2020.8.1(60)

\section{Introduction}

Medication market sustainability is a permanent concern of any society as it is a crucial part of its wellbeing. The changes in the development of this market is influenced by political, economic, social, technological, legal and environmental factors and can have drastic outcomes in the short and long run.

The main objective of the government and society as a whole is proposedly a reduction in new HIV cases in the country, increasing market activity and accessibility of medical treatment. Obviously, it is very hard to achieve all of the above by one drastic policy change. Following the theory of Multi Criteria Decision Making (MCDM) and Analytical Hierarchy Processing (AHP) in particular, the main groups of actors in achieving this goal are:

society - actor, which goal is less infected people;

government - actor, which goal is increasing business activity and reducing prices;

private companies (suppliers/vendors) - actors, which goal is to increase profits.

The composition of control factors is the same as one of the data: the federal budget spending on healthcare, HIV incidence and concluded contract prices for 32 selected INNs.

The dynamics of HIV spread rate should be reflected by the government spending, subsequently affecting the number of concluded contracts in the related medical supply.

This paper not only proposes the concept of AHP on the market of active substances used in treatment of HIV, but also checks the control factors and criteria interconnection and implements Random Forest forecasting model for one of them, enabling the ability for preemptive actions at regulating and achieving one or several objective parameters, mentioned earlier.

\section{Literature review}

The problem of exploiting powerful multiple criteria decision making approaches is indispensable for healthcare organizations while evaluating different alternatives in the presence of varying types of criteria like many researchers wrote for industry and for banking sector (Kucukaltan, 2016; Aky1ld1z, 2015, Onar, 2019; Gul, 2018).

Some of the existing papers, regarding government spending, are focused on the hospital performance metrics (Kumar et al., 2019; Chang et al., 2015; Lee et al., 2019) or regional statistics (Belton and Stewart, 2002; Edmonds et al., 2019; Kruger et al., 2019) which partially influenced our study. Most of the authors were focused on predicting mortality rates compared with government spending, improving healthcare benefits and patient treatment, inequality of services or other related concerns, using advanced statistic technics and neural networks.

The topic of HIV was broadly discussed in multiple studies, including government spending (Beyrer et al., 2017; Haakenstad et al. 2019). It was also reported that Russian Federation has the largest HIV epidemic in Europe (Stuikyte et al., 2019). The current strategy of Russian government is well described in paper (Nyangarika et al., 2018).

The virus itself, its spread rate, health and economic impact was discussed numerous times by many researchers. Some of their works were used by authors to understand the threat and regional situation (Lebedev et al., 2019; Vetrova et al., 2018; King et al., 2019; Pape, 2018). We also looked at the potential active substances used in the treatment of HIV in Russia (Tremblay et al., 2018).

The paper used solutions from several reliable studies of MCDM application for different sectors and cases (Sabaei et al., 2015). There were also researches, concentrated on the evaluation of different methods of MCDM, which guided this study to the strategy applied (Asadabadi et al., 2019). To create a general understanding of the MCDM in healthcare and hospital sector we analyzed the existing literature related to the AHP (Schmidt et al., 2015). Subsequently, we used methods and proposals in application of AHP in the selected sector (Padilla- 


\section{ENTREPRENEURSHIP AND SUSTAINABILITY ISSUES}

ISSN 2345-0282 (online) http://jssidoi.org/jesi/

2020 Volume 7 Number 5 (September)

http://doi.org/10.9770/jesi.2020.8.1(60)

Garrido et al., 2014). One of the researches was also considering the local government spending the country, but it covered the healthcare infrastructure (Kharisma et al., 2019; Mitsek, 2015). Despite that, some of the AHP methods from that paper were partially applied in this study.

In our study, we use Random Forest algorithm as one the most recent decision tree classifiers and regression models, which can be used for various tasks (Browne, 2000; Mikhaylov et al, 2018). Its functionality is used to forecast future values of sum of contract prices (Nyangarika et al., 2019b; Nyangarika et al., 2019a).

There are numerous works, which describe multiple approaches at treating the time-series data using neural networks and, in particular, Random Forest algorithm (Pavlyshenko, 2019; Dingli and Fournier, 2017). But those are mostly concentrated on the publicly available data of trading stock prices or sales, rather than prices of contracts.

The Random Forest or boosting algorithm weren't that popular, but still has some respectful and significant works, which included time-series forecasting and data mining (Lohrmann and Luukka, 2018; Singh Maini and Govinda, 2017; An et al., 2019a; An et al., 2019b; An et al., 2019c; An et al., 2020a).

The authors of this study see AHP techniques and statistical data as an opportunity to accurately predict and advise the future government healthcare spending in regards of HIV treatment.

\section{Methods}

\section{Data sources}

This study is based on the public data provided by Russian Federal State Statistic Service (Rosstat), Ministry of Finance of the Russian Federation and World Health Organization (WHO) via open source. The statistics, related to the internal market situation is granted by Cursor Marketing Ltd. (www.cursor-is.ru). Official government reports of Rosstat and Ministry of Healthcare of the Russian Federation has recently boosted the media activity, regarding increasing HIV incidence in Russia (Holt, 2019; Beyrer et al., 2017; Stuikyte et al., 2019).

In 2018 the federal budget expenditure on healthcare was equal to 537,3 billion RUB (www.minfin.ru) or 7,73 billion USD, as of exchange rate on 30 Dec 2018 (www.cbr.ru). The government spending on healthcare has increased since 2008, but it is still not the highest in reported years. These statistics are ought to represent the active measurements, taken by the Russian government, to prevent or at least slow down the spread of HIV infection in the country.

We included recent statistic concerning overall HIV infected people, Federal budget healthcare spending and the daily contract prices in Russia since Oct 2008 till Feb 2019. This time span was chosen as maximum available for internal market information, thus limiting the number of observations to this period. For the purpose of this study, we use the data only till $31 \mathrm{Dec} 2018$ in the general analysis and the rest is implemented into the model's train and test sets (Mikhaylov, 2018a; Mikhaylov, 2018b; Mikhaylov et al., 2020; An et al, 2020b).

\section{Data structure and statistical analysis}

The Federal budget spending is presented in yearly format, as is HIV incidences statistics. We used this data for brief overview and comparison of market and government data.

The medical treatment of HIV is a complex task (Lebedev et al., 2019; Vetrova et al., 2018; Tremblay et al., 2018; Mikhaylov, 2019), thus we gathered the information, referencing to the 32 INNs and their supplements, which were mentioned as the part of the supply order in the documentation of the concluded contracts. These can be found in the list below: 


\begin{tabular}{|ll|ll|}
\hline 1. & Abacavirum & 17. & Maravirocum \\
2. & Amprenavirum & 18. & Natriinucleospermas \\
3. & Atazanavirum & 19. & Nelfinavirum \\
4. & Darunavirum & 20. & Nevirapinum \\
5. & Didanosinum & 21. & Phosphazidum \\
6. & Dolutegravirum & 22. & Raltegravirum \\
7. & Doravirine & 23. & Rilpivirinum \\
8. & Efavirenzum & 24. & Ritonavirum \\
9. & Elsulfavirinum & 25. & Saquinavirum \\
10. & Emtricitabinum & 26. & Stavudinum \\
11. & Enfuvirtidum & 27. & Tenofovirum \\
12. & Etravirinum & 28. & Tipranavirum \\
13. & Fosamprenavirum & 29. & Treonil \\
14. & Indinavirum & 30. & Valgancyclovirum \\
15. & Lamivudinum & 31. & Zalcitabinum \\
16. & Lopinavirum & 32. & Zidovudinum \\
\hline
\end{tabular}

Furthermore, the study concentrates on the current and historical market situation, related to the INNs mentioned above. This includes region, client, vendor, provider, INN and price of the contract analysis, either overall for the chosen period or top 10 positions yearly.

The paper uses the base method of AHP, proposed by (Saaty, 1987) to establish base connections between goal and factors and come up with possible solutions to the established objective. See figure 1.

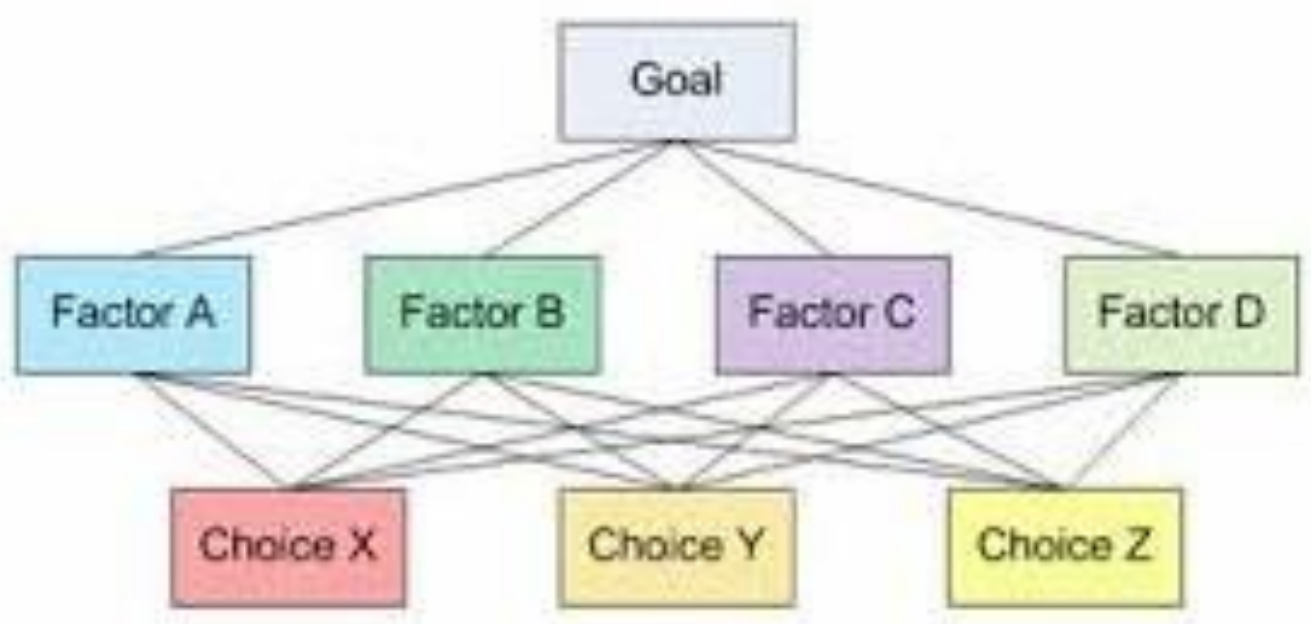

Figure 1. Structure of AHP method 


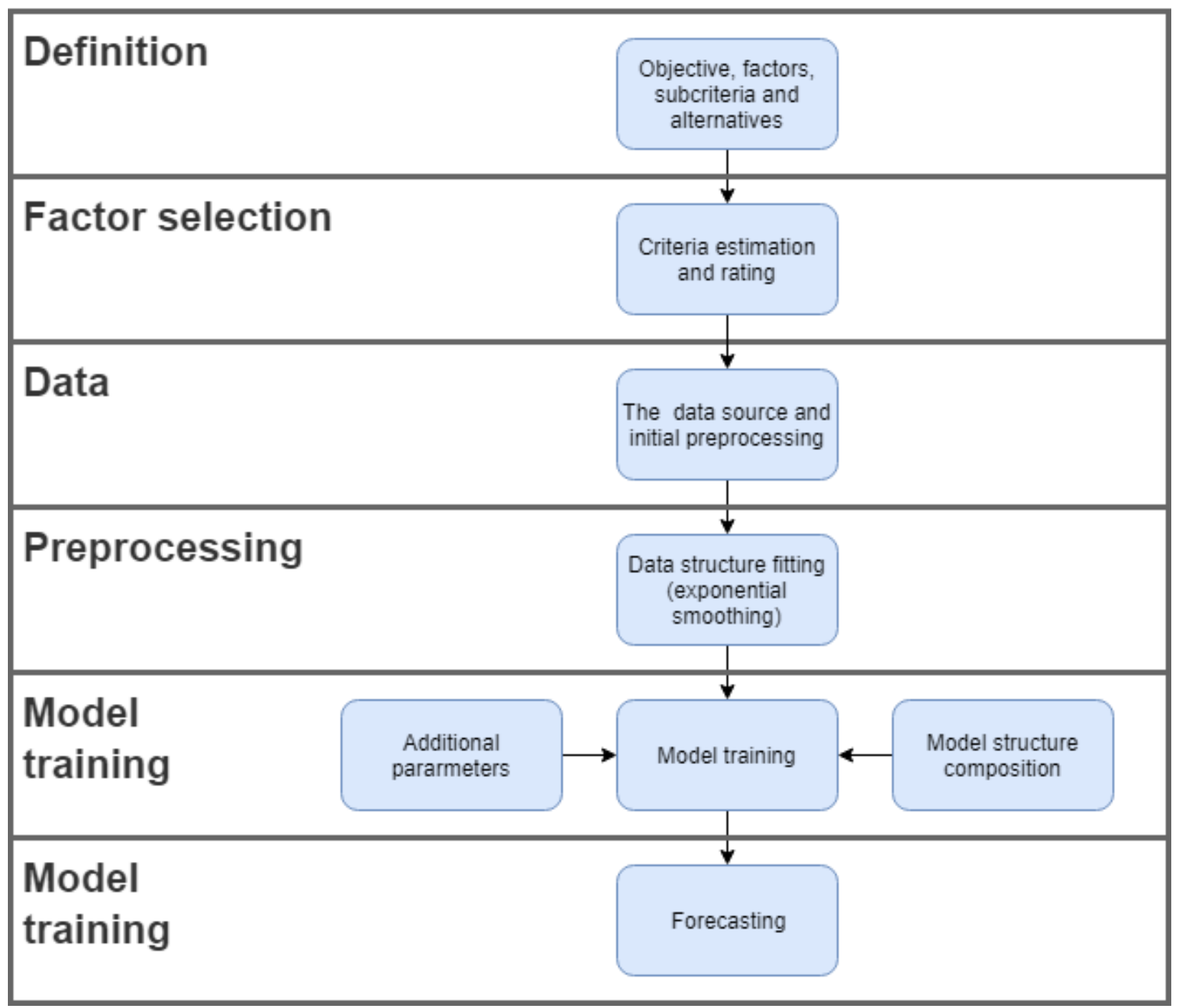

Figure 2. Proposed preprocessing methodology

These methods help to evaluate the factors, which is necessary for reaching the final goal of improving the healthcare procedures and financial planning of government spending, concerning HIV incidence in Russia. By using the AHP, we analyze the significance of each factor and propose the best strategy of resolving the issue, based on the statistics and graphics acquired. See fifure 2.

For this purpose, we also implemented Random Forest regression model for forecasting of concluded contract prices. The source data consisted of final contract price and sum of positions in the particular tender. We used sum of positions as the base of calculations for each INN in contract if possible. Otherwise, the duplicated final price for each INN of the contract was divided by its amount and price of supplied medicine, according to the info, provided in the document. The data also contained some duplicated companies, excluding subsidiaries. Those were replaced by the original full name of the legal entity as of 01 Sep 2019.

Finally, we sorted and combined the data for each year into one table. But the initial figures were incomplete, regarding every day observation, thus creating inconsistency with zero or non-existent values and preventing algorithm from processing it properly. It was decided to use a widely accepted method of simple exponential 
smoothing to deal with highly convoluted data (Ostertagová et al., 2012). The data preparation for the Random Forest model was as follows. In order to achieve confident results, we added Moving average, Exponential Moving Average and the raw data values. This decision was based on the experimental results of this study and others (Gao et al, 2018), concerning predicting future values of the time series.

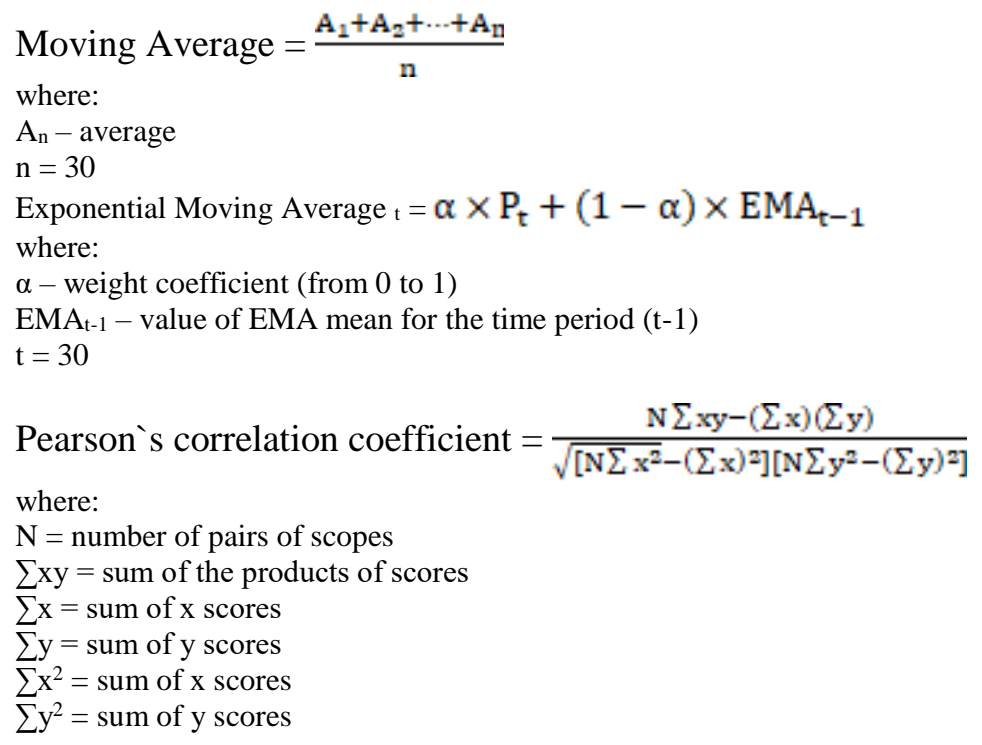

Data preparation and handling is entirely conducted in Microsoft Office Excel (Microsoft Corp.), Python 3.6 (Python Software Foundation), with the following packages: numpy (Zavadskas et al., 2014), matplotlib (Liberatore, 2008) and pandas (Kinney, 2010). We make use of Scikit-learn (Lee and He, 2019) for the random forest regression model.

\section{Prediction algorithm}

Random Forest algorithm is a combination of tree predictors such that each tree depends on the values of a random vector sampled independently and with the same distribution for all trees in the forest. We make use of the method presented in the paper (Khaidem, 2016).

Considering numerical part of the experiment, we followed the (Krauss et al. 2017), whose method guarantees the generalization and accuracy of the prediction model. For the proper model setting we create two sets of data: training and test. First consist of $80 \%$ of historical data, the second - the $20 \%$. The overall amount of days is 3793 and all of them are used in predicting the future parameters.

As mentioned above, we make use of Random forest regression model with bootstrap aggregation. By using the training data, it performs the following procedure (Khaidem, 2016):

1. $\quad$ Selects each group of subsamples in $\mathrm{N}$ training set.

2. Creates a random-forest tree $\mathrm{R}_{\mathrm{n}}$ to the bootstrapped data until the minimum node size is reached, repeating the following steps:

a. Selects $\mathrm{u}$ variables at random from the $\mathrm{U}$ set of all variables.

b. Chooses the best variable from $u$.

c. Splits the node into to new nodes.

3. Output the ensemble of Rn

4. In order to make a prediction of the given test data at each point in the future it averages the output: 


$$
\mathrm{F}^{\prime}=\frac{1}{B} \sum_{i=1}^{B} F i(x)
$$

For the measurements of the model validity, we utilize train and test accuracy score, Oob-score and crossvalidation score, provided by base metrics of scikit-learn. Subsequently, the first one gives an approximation of how well the model is trained, whether it is overfitting or not and its forecasting accuracy. The Oob-score is specific to the Random Forest algorithm. The main base of the random forest is a bootstrap aggregation, which helps to improve the stability and accuracy of the machine learning technics. It also helps to avoid or reduce overfitting and works especially well with decision trees. In this paper for regression, we simply fit the same regression tree many times to bootstrap sampled versions of the training data, thus creating a large amount of end points and average the result (Carayannis, 2018; Dayong et al., 2020; Denisova et al., 2019; Dooyum et al., 2020).

Finally, k-fold cross-validation is a resampling procedure used to evaluate machine learning models on a limited data sample (Browne, 2000; Mikhaylov, 2015). This study uses base 3-fold random data shuffle, in order to evaluate the model.

\section{Results}

\section{Federal budget analysis and HIV incidence in Russia}

The overall spending (Table 1) has increased through the time period of the study in rubles, but its peak was in 2012. Since then, the figure below demonstrates the stable downwards trend, with last specific increase in 2018. Unfortunately, publicly available data does not represent the division by sectors of medical supply, thus unable to provide more than general apprehension.

Table 1. Federal budget spending on healthcare for the studying time period in RUB and USD based on the exchange rates of 01 Jan 2008 .

\begin{tabular}{|c|c|c|c|c|c|c|c|c|c|c|c|}
\hline Billions/RUB & 278,2 & 352,3 & 347,4 & 499,6 & 613,8 & 502,0 & 535,5 & 516,0 & 506,3 & 439,8 & 537,3 \\
\hline Billions/USD & 11,3 & 14,4 & 14,2 & 20,4 & 25,0 & 20,5 & 21,8 & 21,0 & 20,6 & 17,9 & 21,9 \\
\hline
\end{tabular}

Source: Russian Federal State Statistic Service (Rosstat) https://www.gks.ru/ 


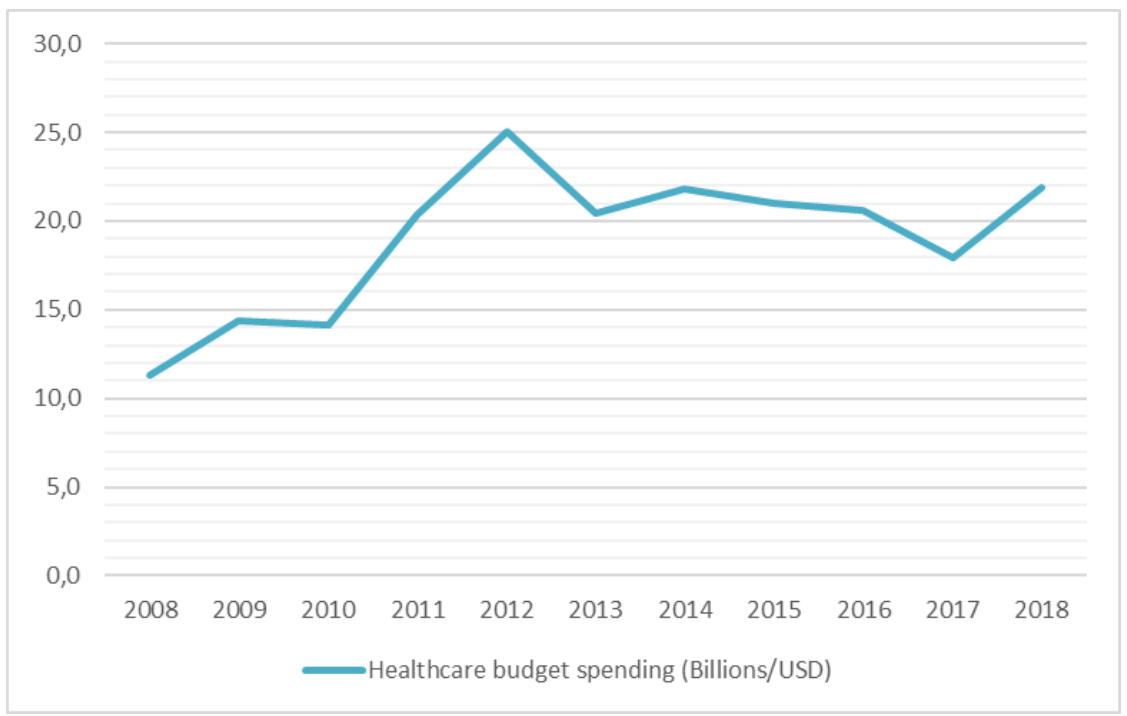

Figure 3. Federal budget spending on healthcare for the studying time period in USD, based on the exchange rates of 01 Jan 2008 . Graphical representation.

These tendencies are most possibly due to the current long-term economic recession in Russian Federation caused by multiple factors (Eberhardt et al., 2015; Viktorov and Abramov, 2019) alongside with government budget policy (Stepanovich, 2018; An et al., 2019; Nyangarika et al., 2019). See figure 2.

To better understand the situation with HIV incidences in Russia we gathered the publicly available statistics, including worldwide. The overall amount of infected people in the world is steadily increasing with each year. Nevertheless, this rate is still lower than the one in Russia, as shows Figure 4 and Table 2.

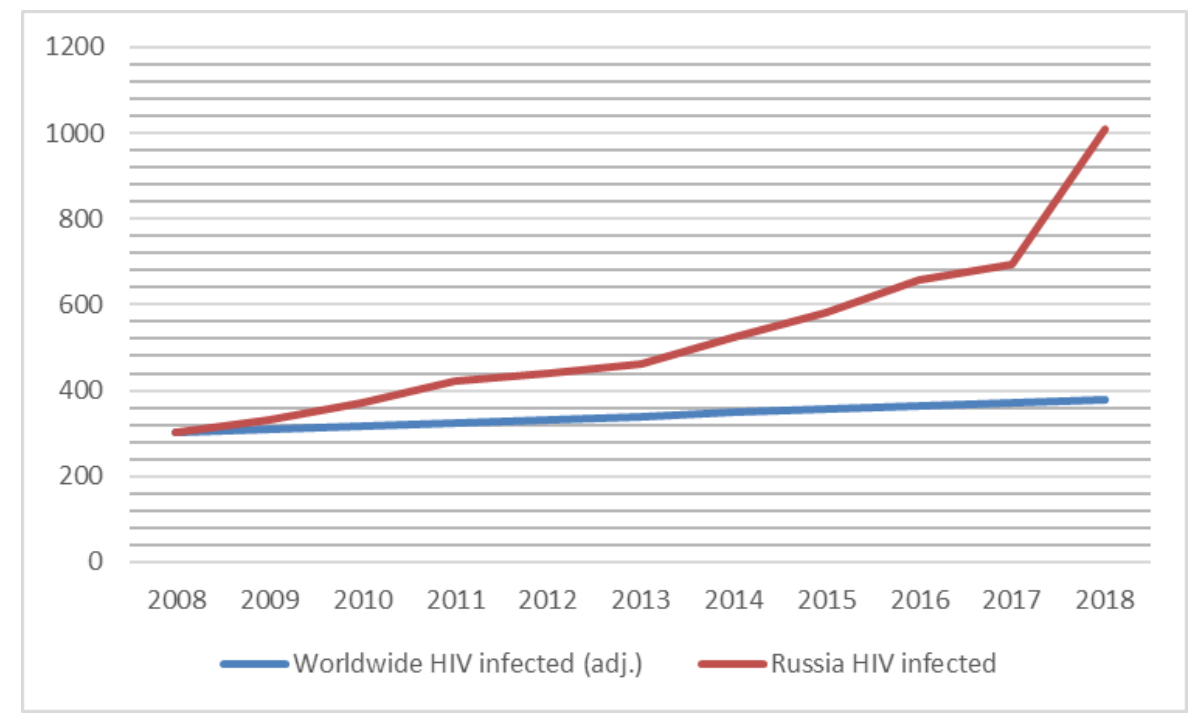

Figure 4. Overall number of HIV infected people among all age groups 
Table 2. Overall number of HIV infected people among all age groups, including newly infected.

\begin{tabular}{|c|c|c|c|c|c|c|c|c|c|c|c|}
\hline Prameter/Year & 2008 & 2009 & 2010 & 2011 & 2012 & 2013 & 2014 & 2015 & 2016 & 2017 & 2018 \\
\hline Worldwide infected (th. People) & 30200 & 30900 & 31700 & 32400 & 33200 & 34000 & 34800 & 35600 & 36400 & 37200 & 37900 \\
\hline Worldwide newly infected (th. People) & 2200 & 2100 & 2100 & 2000 & 2000 & 1900 & 1900 & 1900 & 1800 & 1800 & 1700 \\
\hline HIV infected in Russia (th. People) & 301,3 & 332,9 & 372,9 & 422,3 & 438,4 & 463,3 & 522,6 & 581,7 & 658,1 & 693,1 & 1007,36 \\
\hline Newly HIV infected in Russia (th. People) & 44,1 & 50,7 & 57,2 & 59,6 & 59,7 & 63,6 & 73,5 & 87,3 & 86,9 & 85,8 & 101,34 \\
\hline
\end{tabular}

Source: Russian Federal State Statistic Service (Rosstat) https://www.gks.ru/

Unfortunately, this study does not aim at finding the causation of such drastic changes in figures. But this trend might affect the demand for the selected INNs and medical treatment, increasing government spending and thus inflating the number of concluded contracts and their prices per year (Gura et al., 2020).

\section{Market overview: leading positions}

This section of the study will cover the internal market data considering prices of concluded contracts between private or government owned suppliers and state clients and medical facilities, concerning 32 INN. It is worth noting, that the factor divisions, presented in this section, might play a role in the overall AHP for the established goal, mentioned earlier.

The sum of contract prices shows the clear increase since 2008 and especially in $2014-2018$. This may indicate the general concern and subsequent response of the government officials on the rise of HIV incidence. Although on the figure 5, we can see that peaks in federal budget spending are different from the ones of contract prices. This is most possibly due to the fact that healthcare government spending has its own division of spending budgets per each subsequent region, medical organization and group of medical supplies.

Figure 5. The sum of contract prices of selected INNs for the time period of the study.

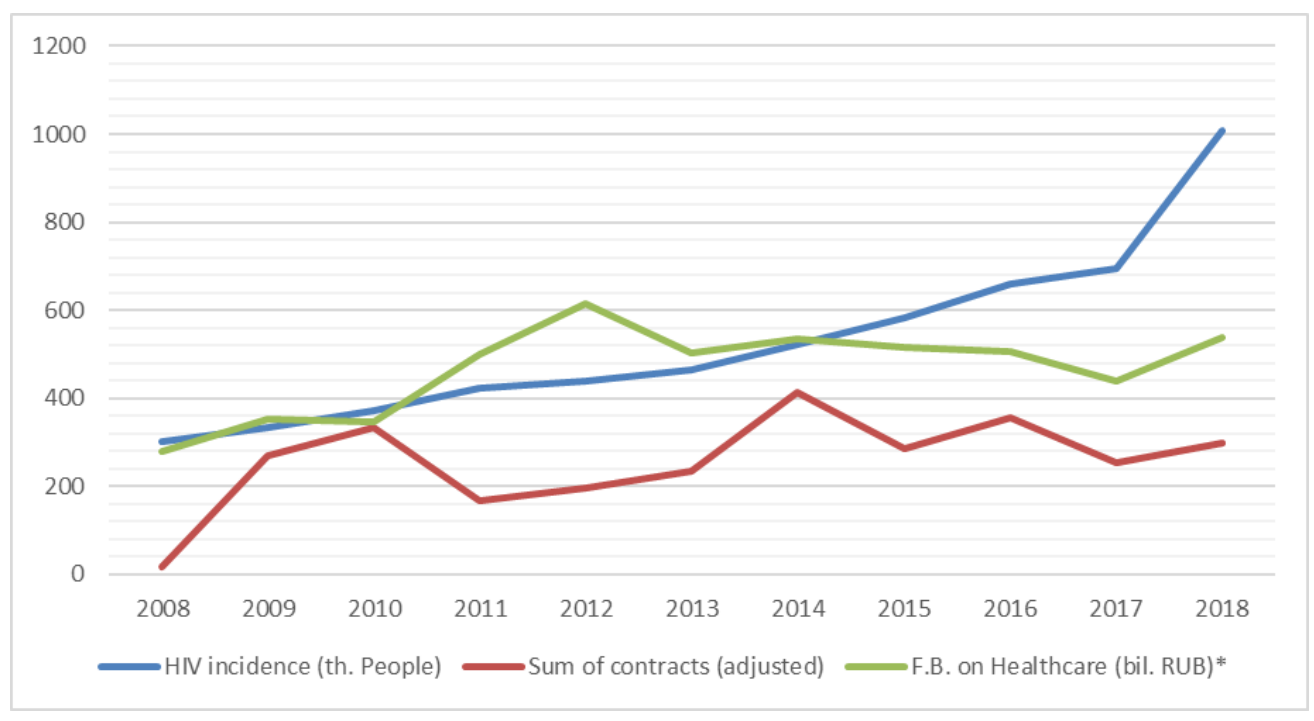




\section{ENTREPRENEURSHIP AND SUSTAINABILITY ISSUES}

ISSN 2345-0282 (online) http://jssidoi.org/jesi/ 2020 Volume 7 Number 5 (September) http://doi.org/10.9770/jesi.2020.8.1(60)

The government spending on selected INNs is better visualized by the comparison of adjusted contract prices and amount of HIV infected people in figure 6. Nevertheless, the figures also indicate slight decrease in sum of contract prices after 2014. This phenomenon might be caused by several factors, including economic crisis, change in internal government policy or any other.

Via this graph we also can see that there is no definitive effect of unadjusted sum of contract prices on the dynamic of HIV spread. It is also may be confirmed by low correlation between these two dataset: Pearson correlation coefficient $(\mathrm{PCC})=0,4152$. Taking this into consideration, we can say that current number of concluded contracts on selected set of HIV related medication does not represent the trend of HIV incidence in Russia, assuming data completeness and fairness of tender auctions. But it almost fits the dynamics of federal budget spending on healthcare overall.

Furthermore, the correlation coefficient of official government spending and sum of concluded contracts is 0,3847. Finally, the PCC of HIV incidence and federal budget on healthcare is 0,495. The results conclude that there is a lack of strong positive connection between these three control criteria. Nevertheless, the 2018 data point visually shows that government has started to react on the issue. We propose further increase in the government spending on these INNs and possible price reduction of tenders, lowering the market barriers for new participants. This should play an important role in increasing of accessibility of the medical care, but would possibly decrease profits of big private companies, as will be described further (Table 3).

Table 3. The comparison of HIV incidence, adjusted sum of contract prices and federal budget spending on healthcare in Russia. *F.B.S. - short for Federal Budget Spending.

\begin{tabular}{|c|c|c|c|c|c|c|c|c|c|c|c|}
\hline HIV incidence (th. People) & 301,3 & 332,9 & 372,9 & 422,3 & 438,4 & 463,3 & 522,6 & 581,7 & 658,1 & 693,1 & 1007,37 \\
\hline Sum of contracts (bil. RUB) & 1688,15 & 26955,6 & 33314,1 & 16589,3 & 19614,9 & 23549,9 & 41281,2 & 28683,8 & 35739,5 & 25498,3 & 29797,9 \\
\hline
\end{tabular}

Source: Russian Federal State Statistic Service (Rosstat) https://www.gks.ru/

This study does not concentrate on the effects of INNs on the medical treatment of HIV, but we analyzed the total proportion of each active substance in terms of total contract prices for the whole observed time period.

These INNs might be widely used or have a high buying price or both. This effect might also indicate the popularity of the medical treatment strategies, which include these types of active substances. Unfortunately, our observations lack sufficient amount of timely data to make better, more definitive conclusions about this particular detail of the market.

Nevertheless, we also analyzed the suppliers, which won and, subsequently, completed the contract with one or multiple medical institutions and government agencies. According to the collected data, the R-Pharm group holds a leading position as a main winner of government tenders and supplier of medical substances in Russia for the duration of studying period. Yet, even in top 10 suppliers we can see in Table 4 some companies stopping their operations on the Russian market in the field of HIV medical treatment, during the same time frame. JSC EmpirePharma has declared bankruptcy in 2015, also being brought into multiple juridical suits (www.dp.ru). 
Table 4. The statistics of contract winners for selected INNs in Russia (th. RUB).

\begin{tabular}{|l|l|l|l|l|l|l|l|l|l|}
\hline Year/Company & $\begin{array}{l}\text { R-Pharm } \\
\text { Group }\end{array}$ & Pharmstandard & $\begin{array}{l}\text { Multiple } \\
\text { winners }\end{array}$ & $\begin{array}{l}\text { Cosmopharm } \\
\text { Ltd }\end{array}$ & $\begin{array}{l}\text { Empire- } \\
\text { Pharma }\end{array}$ & Pharmimex & $\begin{array}{l}\text { Biotech } \\
\text { Ltd }\end{array}$ & $\begin{array}{l}\text { Irvin } \\
\text { Ltd }\end{array}$ & \begin{tabular}{l} 
Rosta \\
\hline 2009
\end{tabular} \\
\hline 2186264 & - & - & 6555 & 3120023 & - & 1332964 & 1797456 & 1930895 \\
\hline 2010 & 3030451 & 11289 & - & 6270 & 4710235 & - & 240036 & 2151872 & 1251674 \\
\hline 2012 & 5919673 & 1764625 & - & 12693 & 0 & - & 109055 & 22524 & 345356 \\
\hline 2013 & 7960662 & 2633948 & - & - & 1861 & 915945 & - & - \\
\hline 2014 & 8733644 & 2290311 & 0 & 1643645 & 3 & 1897211 & - & 61783 & 1284 \\
\hline 2015 & 9362010 & 2181228 & 3792204 & 1711123 & 11254 & 1448387 & - & 225383 & 1410346 \\
\hline 2016 & 9414030 & 1382173 & 4151813 & 1728363 & - & 1467914 & 0 & 146518 & 128786 \\
\hline 2017 & 10262806 & 2000997 & 5835953 & 2022340 & - & 866766 & 1013741 & 18903 & - \\
\hline 2018 & 13747741 & 3548231 & 515135 & 2119840 & - & 751043 & 2064063 & 506833 & - \\
\hline Total & 13226211 & 4501009 & 917360 & 612893 & - & 26860 & 1025436 & 335604 & - \\
\hline
\end{tabular}

Source: Russian Federal State Statistic Service (Rosstat) https://www.gks.ru/

If we look closely at the government contractors, who act on the side of the client - the biggest share possesses the Ministry of Healthcare of Russian Federation, closely followed by the Ministry of Healthcare of Moscow region and multiple customers. This definition may combine from several to hundreds of government and partially government controlled organizations. It is used in the official contract documentation, thus unable being avoided. Consequently, we can observe the trend of increasing dominance of the Ministry of Healthcare in the recent years, but a period of 2013 - 2015 is confirming the statement, mentioned above, about the short term change of the governmental policy to diversify some of the spending from big market players in this particular time period.

We also can say that the local healthcare institutions statistics is similar to the high level of reported HIV incidence in the region, especially in Rostov, Sverdlovskiy, Chelyabinsk and Krasnodar region (Beyrer et al., 2017).

For example, we can assume that the companies, which operate in the region with the highest incidence are receiving bigger portion of federal budget, thus able to spend more than other government institutions in other regions. The Table 6 clearly indicates a trend of the government response on the current situation. In addition to that, the spending of the central regions, such as Moscow is increased, because there are concentrated many health organizations, hospitals and AIDS hospices, working country-wise (Nie et al., 2020).

Finally, for this section we shall look at the vendors of the study selected INNs and give a small inquiry about the market situation. To our regret, the publicly available information, relating to the structure of import and export of medical supplies in Russia is mostly unavailable for the observed companies. But the existing data shows that one of the biggest pharmaceutical corporations in the world are playing a very important role on the medication market, concerning HIV treatment in Russia.

The findings in this paper are highly related to the field of MCDM and AHP. The study describes an empirical research, concerning the application of AHP in the sphere of medication market using the HIV incidence related 


\section{ENTREPRENEURSHIP AND SUSTAINABILITY ISSUES}

ISSN 2345-0282 (online) http://jssidoi.org/jesi/

2020 Volume 7 Number 5 (September)

http://doi.org/10.9770/jesi.2020.8.1(60)

statistics and demonstrates the improvement of AHP concept by applying the Random Forest regression model for forecasting of one of the factors. Thus showing the positive results for potential adaptation of such tool in future studies (Lopatin, 2020; Lopatin, 2019).

The paper developed the concepts of exploiting powerful multiple criteria decision-making approaches (Kucukaltan, 2016; Aky1ldı, 2015, Onar, 2019; Gul, 2018; Mutalimov et al., 2020). It evaluate different alternatives in the presence of varying types of criteria such as: HIV spread rate, government spending, and the number of concluded contracts.

The paper also check the applicability of MCDM for Russian health care sector like foreign researchers (Sabaei et al., 2015). The paper did not develop the study about the applied strategy (Asadabadi et al., 2019; Schmidt et al., 2015). However, It used methods in application of AHP in the healthcare sector like Padilla-Garrido et al. (2014). We covered the healthcare infrastructure of Russian economy like the one It was done for Java region in Indonesia (Kharisma et al., 2019) and regions of Russia (Mitsek, 2015).

In addition, the paper developed the recent decision tree classifiers and regression models (Browne, 2000), which can be used for forecast future values of sum of contract prices (Litvishko and Litvishko, 2019; Litvishko et al., 2019a; Litvishko et al., 2019b).

The paper use new data sources and transforms the traditional approach focused on the hospital performance metrics (Kumar et al., 2019; Chang et al., 2015; Lee et al., 2019; Mikhaylov and Sokolinskaya, 2019; Mikhaylov et al., 2019; Mikhaylov, 2020) or regional statistics (Belton and Stewart, 2002; Edmonds et al., 2019; Kruger et al., 2019).

The research proved the ideas about the government spending (Beyrer et al., 2017; Haakenstad et al. 2019) and support position Stuikyte et al. (2019) about dangerous HIV situation in Russia and largest HIV epidemic in Europe (Alwaelya et al., 2020; Yumashev and Mikhaylov, 2020).

In the future research we recommend to understand the threat and regional situation and develop the direction of international researchers (Lebedev et al., 2019; Vetrova et al., 2018; King et al., 2019; Pape, 2018). We also contributed the analysis of the treatment of HIV in Russia by Tremblay et al. (2018).

\section{Conclusion}

The current spread of HIV incidence in Russia is increasing (Holt, 2019). The cause of the problem may lie in the field of economic problems and low rate of economic growth (Eberhardt, and Menkiszak, 2015). The recent years saw the decline in government budget spending on healthcare, thus affecting the situation in negative way. The identification of the specific factors, their influence and future trends, might help to develop new management decision making strategies, regarding the issue.

To evaluate these economic factors, we used the methods of MCDM model (AHP), graphical and regression analysis in the form of Random Forest models and correlation coefficients. We identified the possible alternative decision strategies for improving the healthcare budget spending, which should help to potentially bring to a halt or even reduce the HIV incidence in Russia. Furthermore, we made a prediction model to forecast future real market values for concluded contracts of the selected medication, used in the treatment of HIV.

The current studies show the potential for MCDM techniques in local regions, using public data (Schmidt et al., 2015). This paper proposes the same methods, bur at much bigger scale with additional tools, like Random Forest regression.

If we look at the data representing actual regional HIV incidence in Russia, it is clear that there is a partial similarity of affected regions between our results and conclusions of other authors (Beyrer et al., 2017; 


\section{ENTREPRENEURSHIP AND SUSTAINABILITY ISSUES}

ISSN 2345-0282 (online) http://jssidoi.org/jesi/ 2020 Volume 7 Number 5 (September) http://doi.org/10.9770/jesi.2020.8.1(60)

Haakenstad et al. 2019). It was also discovered that there is no strong positive correlation between market data, federal budget spending and HIV spread rate, which, to our knowledge, was not reported in previous studies.

Methods of predicting factors for AHP models with wider data points could potentially lead to improved results in managerial decision making process and thus increase efficiency of government budget spending on healthcare.

Assuming data completeness and fairness of tender auctions, we can say that current number of concluded contracts on selected set of HIV related medication does not represent the trend of HIV incidence in Russia, as are other criteria, thus rendering them to be independent. The proposed concept, regarding AHP with existing data, has shown its effectiveness in developing of strategy for the potential improvement of HIV incidence dynamics, business activity and accessibility of medical care in Russian Federation (Shedenov et al, 2019; Veynberg and Titov, 2017; Veynberg and Popov, 2016; Veynberg et al., 2015; Mikhaylov and Tarakanov, 2020).

Overall situation indicates an increase in government expenses on the supply of the selected INNs in 2017-2018, boosting the activity of market participants in the field of medical tenders. The study concludes that it would be highly efficient to prolong this trend and diversify the amount of participants in the market of government tenders for the selected active substances (Yumashev et al., 2020).

The proposed approach and unique initial data has shown a substantial result of more than $82 \%$ average accuracy at predicting the sum of contract prices for the selected INNs at the 3-year time period. The received figures are effective in predicting the factors' behavior in future. It can be used for improved modulation of AHP and consequently, the overall accuracy of the model structure.

The Random Forest model was approved as an efficient tool at forecasting the sum of contract prices in the longterm time scales. This model may be used as a guideline for the suppliers, vendors, society decision makers and government companies, for forecasting of future business activities and reduction of HIV incidence relating to the market of INNs used in its medical treatment or any other group of active substances.

Further studies will concentrate on incorporating other factors into the similar models and development of new approaches of MCDM and Random Forest model combination at the medication market prediction.

\section{References:}

Akyıldız, B., Kadaifçi, Ç., Topcu, Y.İ. (2015). A decision framework proposal for customer order prioritization: A case study for a structural steel company, International Journal of Production Economics, 169/1, 21-30. https://doi.org/10.1016/j.ijpe.2015.07.004

Alwaelya, S.A., Yousif N.B.A., Mikhaylov A. (2020). Emotional Development in Preschoolers and Socialization. Early child development and care, 190(6). https://doi.org/10.1080/03004430.2020.1717480

An, J., Mikhaylov, A., Kim, K. (2020a). Machine Learning Approach in Heterogeneous Group of Algorithms for Transport Safety-Critical System. Applied Sciences, 10(8), 2670; https://doi.org/10.3390/app10082670

An, J., Mikhaylov, A., Jung, S.-U. (2020b). The Strategy of South Korea in the Global Oil Market. Energies, 13(10), 2491; https://doi.org/10.3390/en13102491

An, J., Mikhaylov, A., Sokolinskaya, N. (2019a). Machine learning in economic planning: ensembles of algorithms. Journal of Physics: Conference Series, 1353, 012126 https://doi.org/10.1088/1742-6596/1353/1/012126

An, J., Mikhaylov, A., Sokolinskaya, N. (2019b). Oil incomes spending in sovereign fund of Norway (GPFG). Investment Management and Financial Innovations, 16(3), 10-17. https://doi.org/10.21511/imfi.16(3).2019.02 


\section{ENTREPRENEURSHIP AND SUSTAINABILITY ISSUES}

ISSN 2345-0282 (online) http://jssidoi.org/jesi/ 2020 Volume 7 Number 5 (September) http://doi.org/10.9770/jesi.2020.8.1(60)

An, J., Mikhaylov, A., Moiseev, N. (2019c). Oil Price Predictors: Machine Learning Approach. International Journal of Energy Economics and Policy, 9(5), 1-6. https://doi.org/10.32479/ijeep.7597

Asadabadi, M.R., Chang, E., Saberi, M. (2019). Are MCDM methods useful? A critical review of Analytic Hierarchy Process (AHP) and Analytic Network Process (ANP). Cogent Engineering, 6(1). https://doi.org/10.1080/23311916.2019.1623153

Belton, V. \& Stewart, T. (2002). Multiple Criteria Decision Analysis: An Integrated Approach. Dordrecht: Kluwer Academic Publishers. London: Kluwer.

Beyrer, C., Wirtz, A.L., O'Hara, G., Léon, N. and Kazatchkine, M. (2017). The expanding epidemic of HIV-1 in the Russian Federation. PLOS Medicine, 14(11), p.e1002462. https://doi.org/10.1371/journal.pmed.1002462

Browne, M.W. (2000). Cross-Validation Methods. Journal of Mathematical Psychology, 44(1), 108-132. https://doi.org/10.1006/jmps.1999.1279

Carayannis, E., Ferreira, J., Jalali, M. \& Ferreira, F. (2018). MCDA in knowledge-based economies: Methodological developments and real-world applications. Technological Forecasting and Social Change, Vol. 131, 1-3. https://doi.org/10.1016/j.techfore.2018.01.028

Chang, H. (2015). Book Review: Data-Driven Healthcare \& Analytics in a Big Data World. Healthcare Informatics Research, $21(1)$, p.61. https://doi.org/10.4258/hir.2015.21.1.61

Dayong, N, Mikhaylov, A, Bratanovsky, S, Shaikh, Z.A., Stepanova, D. (2020). Mathematical modeling of the technological processes of catering products production. Journal of Food Process Engineering, 43(2). https://doi.org/10.1111/jfpe.13340

Denisova, V., Mikhaylov, A., Lopatin, E. (2019). Blockchain Infrastructure and Growth of Global Power Consumption. International Journal of Energy Economics and Policy, 9(4), 22-29. https://doi.org/10.32479/ijeep.7685

Dingli, A., Fournier, K.S. (2017). Financial Time Series Forecasting - A Machine Learning Approach. Machine Learning and Applications: An International Journal, 4(1/2/3), 11-27. https://doi.org/10.18178/ijmlc.2017.7.5.632

Dooyum, U.D., Mikhaylov, A., Varyash, I. (2020). Energy Security Concept in Russia and South Korea. International Journal of Energy Economics and Policy, 2020, 10(4), 102-107. https://doi.org/10.32479/ijeep.9116

Eberhardt, A., Menkiszak, M. (2015) The economic and financial crisis in Russia - background, symptoms and prospects for the future. OSW Report 02/2015. https://www.osw.waw.pl/en/publikacje/osw-report/2015-02-06/economic-and-financial-crisis-russia-backgroundsymptoms-and

Edmonds, S., Hajizadeh, M. (2019). Assessing progressivity and catastrophic effect of out-of-pocket payments for healthcare in Canada: 2010-2015. The European Journal of Health Economics, 20(7), 1001-1011. https://doi.org/10.1007/s10198-019-01074-x

Gao, T., Chai, Y. (2018). Improving Stock Closing Price Prediction Using Recurrent Neural Network and Technical Indicators. Neural Computation. 30. 1-22. https://doi.org/10.1162/neco_a_01124

Gül, S., Kabak, Ö., Topcu, Y.İ. (2018). An OWA Operator-based Cumulative Belief Degrees Approach for Credit Rating, International Journal of Intelligent Systems, 33/5, 998-1026. https://doi.org/10.1002/int.21909

Gura, D., Mikhaylov, A., Glushkov, S., Zaikov, M., Shaikh Z.A. (2020). Model for estimating power dissipation along the interconnect length in single on-chip topology. Evolutionary Intelligence. https://doi.org/10.1007/s12065-020-00407-7

Haakenstad, A., Moses, M.W., Tao, T., Tsakalos, G., Zlavog, B., Kates, J., Wexler, A., Murray, C.J.L. and Dieleman, J.L. (2019). Potential for additional government spending on HIV/AIDS in 137 low-income and middle-income countries: an economic modelling study. The Lancet HIV, 6(6), pp.e382-e395. https://doi.org/10.1016/s2352-3018(19)30038-4

Holt, E. (2019). Disputed figures do not hide Russia’s HIV epidemic. The Lancet HIV, 6(4), pp.e216-e217.

Keeney, R. (1992). Value-focused Thinking: A Path to Creative Decision Making. Harvard: University Press Harvard. https://doi.org/10.1016/s2352-3018(19)30085-2

Khaidem, L., Saha, S., Dey, S.R. (2016). Predicting the direction of stock market prices using random forest. ArXiv, abs/1605.00003. 


\section{ENTREPRENEURSHIP AND SUSTAINABILITY ISSUES}

ISSN 2345-0282 (online) http://jssidoi.org/jesi/ 2020 Volume 7 Number 5 (September)

http://doi.org/10.9770/jesi.2020.8.1(60)

Kharisma, B., Remi, S.S., Noor, A.M.Z. (2019). Setting Local Government Priorities in Healthcare Infrastructure Using the Analytical Hierarchy Process Approach: The Cases of Local Governments in West Java Province. Public Administration Issues, 0(5), 155-182. https://doi.org/10.17323/1999-5431-2019-0-5-155-182

King, E.J., Niccolai, L.M., Eritsyan, K.U., Heimer, R., Levina, O.S. (2019). HIV testing among people who inject drugs in Ivanovo and Novosibirsk, Russia. Central European Journal of Public Health, 27(1), 50-53. https://doi.org/10.21101/cejph.a4831

Kiseleva, P. (2018). Regional inflation in Russia and ways of controlling it. R-Economy, 4(2), 39-43. https://doi.org/10.15826/recon.2018.4.2.006

Krauss, C., Do, X.A., Huck, N. (2017). Deep neural networks, gradient-boosted trees, random forests: Statistical arbitrage on the S\&P 500. European Journal of Operational Research, 259(2), pp.689-702.

Kruger, B.P., Brown, J.R. (2019). Healthcare spending in the State of Louisiana. BMC Health Services Research, 19(1). https://doi.org/10.1186/s12913-019-4275-y

Kucukaltan, B., Irani, Z., Aktas, E. (2016). A decision support model for identification and prioritization of key performance indicators in the logistics industry. Computers in Human Behavior, 65, 346-358. https://doi.org/10.1016/j.chb.2016.08.045

Kumar, S., Singh, M. (2019). Big data analytics for healthcare industry: impact, applications, and tools. Big Data Mining and Analytics, 2(1), 48-57. https://doi.org/10.26599/bdma.2018.9020031

Lebedev, A., Lebedeva, N., Moskaleychik, F., Pronin, A., Kazennova, E., Bobkova, M. (2019). Human Immunodeficiency Virus-1 Diversity in the Moscow Region, Russia: Phylodynamics of the Most Common Subtypes. Frontiers in Microbiology, 10. https://doi.org/10.3389/fmicb.2019.00320

Lee, J., He, Q.P. (2019). Understanding the effect of specialization on hospital performance through knowledge-guided machine learning. Computers \& Chemical Engineering, 125, 490-498. https://doi.org/10.1016/j.compchemeng.2019.03.040

Liberatore, M.J., Nydick, R.L. (2008). The analytic hierarchy process in medical and health care decision making: A literature review. European Journal of Operational Research, 189(1), 194-207. https://doi.org/10.1016/j.ejor.2007.05.001

Liefert, W.M., Liefert, O., Seeley, R., Lee, T. (2019). The effect of Russia's economic crisis and import ban on its agricultural and food sector. Journal of Eurasian Studies, 10(2), 119-135. https://doi.org/10.1177/1879366519840185

Litvishko, O., Veynberg, R., Bodrov, I. (2019a) Investment potential of the football industry. Journal of Physical Education and Sport, $19(4), 362,2390-2399$

Litvishko, O.V., Vyprikov, D.V., Lubyshev, E.A. (2019b). Financial and economic performance rating factors in national football industry. Teoriya i Praktika Fizicheskoy Kultury, (11), 20-22

Litvishko, V.S., Litvishko, O.V. (2019). Environmental aspects of using microencapsulated malathion. Research Journal of Pharmaceutical, Biological and Chemical Sciences, 7(6), 3114-3122.

Lohrmann, C., Luukka, P. (2018). Classification of intraday S\&P500 returns with a Random Forest. International Journal of Forecasting. 35. https://doi.org/10.1016/j.ijforecast.2018.08.004.

Lopatin, E. (2020). Cost of Heating Pump Systems in Russia. International Journal of Energy Economics and Policy, 10(3). https://doi.org/10.32479/ijeep.9056

Lopatin, E. (2019). Assessment of Russian banking system performance and sustainability. Banks and Bank Systems, 14(3), 202-211. https://doi.org/10.21511/bbs.14(3).2019.17

Mikhaylov, A., Moiseev, N., Aleshin, K., Burkhardt, T. (2020). Global climate change and greenhouse effect. Entrepreneurship and Sustainability Issues, 7(4), 2897-2913. http://doi.org/10.9770/jesi.2020.7.4(21)

Mikhaylov A, Tarakanov, S. (2020). Development of Levenberg-Marquardt theoretical approach for electric network. Journal of Physics: Conference Series, 1515, 052006 https://doi.org/10.1088/1742-6596/1515/5/052006 


\section{ENTREPRENEURSHIP AND SUSTAINABILITY ISSUES}

ISSN 2345-0282 (online) http://jssidoi.org/jesi/ 2020 Volume 7 Number 5 (September)

http://doi.org/10.9770/jesi.2020.8.1(60)

Mikhaylov, A, Sokolinskaya, N. (2019). Russian banks after sanctions of 2014. Orbis, 15(44), 55-65. http://www.revistaorbis.org.ve/pdf/44/art5.pdf

Mikhaylov, A. (2020). Geothermal Energy Development in Iceland. International Journal of Energy Economics and Policy, 2020, 10(4), 31-35. https://doi.org/10.32479/ijeep.9047

Mikhaylov, A., Sokolinskay, N., Lopatin, E. (2019). Asset allocation in equity, fixed-income and cryptocurrency on the base of individual risk sentiment. Investment Management and Financial Innovations, 16(2), 171-181. https://doi.org/10.21511/imfi.16(2).2019.15

Mikhaylov, A. (2019). Oil and Gas Budget Revenues in Russia after Crisis in 2015. International Journal of Energy Economics and Policy, 9(2), 375-380. https://doi.org/10.32479/ijeep.6635

Mikhaylov, A., Sokolinskaya, N., Nyangarika, A. (2018) Optimal Carry Trade Strategy Based on Currencies of Energy and Developed Economies. Journal of Reviews on Global Economics, 7, 582-592. https://doi.org/10.6000/1929-7092.2018.07.54

Mikhaylov, A. (2018a). Pricing in Oil Market and Using Probit Model for Analysis of Stock Market Effects. International Journal of Energy Economics and Policy, 8(2), 69-73. https://www.econjournals.com/index.php/ijeep/article/view/5846

Mikhaylov, A. (2018b). Volatility Spillover Effect between Stock and Exchange Rate in Oil Exporting Countries. International Journal of Energy Economics and Policy, 8(3), 321-326. https://www.econjournals.com/index.php/ijeep/article/view/6307

Mikhaylov, A. (2015). Oil and gas budget revenues in 2015: forecast and risks. Financial journal, 2, 47-54. https://www.nifi.ru/images/FILES/Journal/Archive/2015/2/statyi_2015_2/06_mikhailov.pdf

Mitsek, S.A. (2015). Model of economic growth, inflation and international trade in Russian Federation. IFAC-PapersOnLine, 48(25), 1-5. https://doi.org/10.1016/i.ifacol.2015.11.049

Mutalimov, V, Kovaleva, I, Mikhaylov, A, Stepanova, D. (2020). Methodology comprehensive assessment of the business environment in the regions of Russia: introducing business environment into education system. Journal of Entrepreneurship Education, 23(1). https://www.abacademies.org/articles/Methodology-comprehensive-assessment-of-the-business-environment-1528-2651-23-1-512.pdf

Nie, D., Panfilova, E., Samusenkov, V., Mikhaylov, A. (2020) E-Learning Financing Models in Russia for Sustainable Development. Sustainability, 12(11), 4412. https://doi.org/10.3390/su12114412.

Nyangarika, A., Mikhaylov, A., Tang, B.-J. (2018). Correlation of Oil Prices and Gross Domestic Product in Oil Producing Countries. International Journal of Energy Economics and Policy, 8(5), 42-48. Retrieved from https://www.econjournals.com/index.php/ijeep/article/view/6802

Nyangarika, A., Mikhaylov, A., Richter, U. (2019a). Influence Oil Price towards Economic Indicators in Russia. International Journal of Energy Economics and Policy, 9(1), 123-129. https://doi.org/10.32479/ijeep.7597

Nyangarika, A., Mikhaylov, A., Richter, U. (2019b). Oil Price Factors: Forecasting on the Base of Modified Auto-regressive Integrated Moving Average Model. International Journal of Energy Economics and Policy, 9(1), 149-160. https://doi.org/10.32479/ijeep.6812

Onar, S. C., Aktas, E., Topcu, Y. I. (2010). A Multi-Criteria Evaluation of Factors Affecting Internet Banking in Turkey. In Multiple Criteria Decision Making for Sustainable Energy and Transportation Systems (pp. 235-246). Springer, Berlin, Heidelberg. https://doi.org/10.1007/978-3-642-04045-0_20

Ostertagová, E., Ostertag, O. (2012). Forecasting using simple exponential smoothing method. Acta Electrotechnica et Informatica, 12(3). https://doi.org/10.2478/v10198-012-0034-2

Padilla-Garrido, N., Aguado-Correa, F., Cortijo-Gallego, V., López-Camacho, F. (2014). Multicriteria Decision Making in Health Care Using the Analytic Hierarchy Process and Microsoft Excel. Medical Decision Making, 34(7), pp.931-935.

Pape, U. (2018). Framing the Epidemic: NGOs and the Fight Against HIV/AIDS in Russia. Russian Politics, 3(4), 486-512. https://doi.org/10.1177/0272989x14534533

Pavlyshenko, B. (2019). Machine-Learning Models for Sales Time Series Forecasting. Data, 4(1), 15. https://doi.org/10.3390/data4010015 


\section{ENTREPRENEURSHIP AND SUSTAINABILITY ISSUES}

ISSN 2345-0282 (online) http://jssidoi.org/jesi/ 2020 Volume 7 Number 5 (September) http://doi.org/10.9770/jesi.2020.8.1(60)

Saaty, R.W. (1987). The Analytic Hierarchy Process-What It Is and How It Is Used. Mathematical Modelling, 9, 161-176. http://dx.doi.org/10.1016/0270-0255(87)90473-8

Sabaei, D., Erkoyuncu, J., Roy, R. (2015). A Review of Multi-criteria Decision Making Methods for Enhanced Maintenance Delivery. Procedia CIRP, 37, 30-35. https://doi.org/10.1016/j.procir.2015.08.086

Schmidt, K., Aumann, I., Hollander, I., Damm, K., von der Schulenburg, J.-M.G. (2015). Applying the Analytic Hierarchy Process in healthcare research: A systematic literature review and evaluation of reporting. BMC Medical Informatics and Decision Making, [online] 15(1). https://doi.org/10.1186/s12911-015-0234-7

Shedenov, U., Litvishko, O., Kazbekov, B., Suyunchaliyeva, M., Kazbekova, K. (2019). Improvement of ecological tourism on the principles of sustainable economic development. E3S Web of Conferences 135, 04047.

Singh Maini, S., Govinda, K. (2017). Stock Market Prediction using Data Mining Techniques. IEEE 2017 International Conference on Intelligent Sustainable Systems (ICISS). https://doi.org/10.1109/ISS1.2017.8389253

Stepanovich, A. (2018). Reform of the Russian Healthcare System and the Foreign Dimension of Russian Health Policies, Russian Politics, 3(1), 114-134. https://doi.org/10.1163/2451-8921-00301006

Stuikyte, R., Barbosa, I., Kazatchkine, M. (2019). Getting to grips with the HIV epidemic in Russia. Current Opinion in HIV and AIDS, 14(5), pp.381-386. https://doi.org/10.1097/coh.0000000000000573

Tremblay, G., Chounta, V., Piercy, J., Holbrook, T., Garib, S.A., Bukin, E.K. and Punekar, Y.S. (2018). Cost-Effectiveness of Dolutegravir as a First-Line Treatment Option in the HIV-1-Infected Treatment-Naive Patients in Russia. Value in Health Regional Issues, 16, pp.7480. https://doi.org/10.1016/j.vhri.2018.08.001

Vetrova, M.V., Aleksandrova, O.V., Paschenko, A.E., Toropov, S.E., Rassokhin, V.V., Abyshev, R.A., Levina, O.S., Niccolai, L.M. and Heimer, R. (2018). Early stages of HIV treatment cascade in people living with HIV in Saint-Petersburg, Russia. AIDS Care, 30(7), 857862. https://doi.org/10.1080/09540121.2017.1417536

Veynberg, R.R., Titov, V.A. (2017). Business Processes of Managing Media Assets: Technology and Practice of Implementation MAMClass Systems. Advanced science letters, 25, 1: 66-69, https://doi.org/10.1166/asl.2019.13188

Veynberg, R., Popov, A. (2016). Engineering and development of business rules management systems as a part of intelligent DSS. International Journal of Applied Engineering Research, 11(3), 1797-1802, 2016.

Veynberg, R.R., Varfolomeeva, A., Grigoryeva, K. (2015). Intelligent simulation models based on business rules approach in banking sector (WIP). Simulation Series 47(10), 397-402.

Viktorov, I., Abramov, A. (2019). The 2014-15 Financial Crisis in Russia and the Foundations of Weak Monetary Power Autonomy in the International Political Economy. New Political Economy, 1-24. https://doi.org/10.1080/13563467.2019.1613349

Yumashev A and Mikhaylov A. (2020) Development of Polymer Film Coatings with High Adhesion to Steel Alloys and High Wear Resistance. Polymer Composites, 1-6. https://doi.org/10.1002/pc.25583

Yumashev, A., Ślusarczyk, B., Kondrashev, S., Mikhaylov, A. (2020). Global Indicators of Sustainable Development: Evaluation of the Influence of the Human Development Index on Consumption and Quality of Energy. Energies, 13 , 2768. https://doi.org/10.3390/en1311276

Zavadskas, E., Turskis, Z. Kildiené, S. (2014). State of art surveys of overviews on MCDM/MADM methods. Technological and Economic Development of Economy, 20(1), 165-179. https://doi.org/10.3846/20294913.2014.892037 


\section{ENTREPRENEURSHIP AND SUSTAINABILITY ISSUES}

ISSN 2345-0282 (online) http://jssidoi.org/jesi/ 2020 Volume 7 Number 5 (September) http://doi.org/10.9770/jesi.2020.8.1(60)

Vladislav TRUBNIKOV holds position of Laboratory Assistant in Worcester Polytechnic Institute, Worcester, United States. He is an author of several scientific publications and conference papers indexed in scientific bases. He also was of laboratory assistant in Financial University under the Government of the Russian Federation (2017-2018). His subject area is the concept of Analytic Hierarchy Processing (AHP) and implements Random Forest forecasting model. He made research about China energy policy (Evidence of China-Russia cooperation).

ORCID ID: https://orcid.org/0000-0002-5865-2322

Artur MEYNKHARD is graduated Financial University under the Government of the Russian Federation. He is Laboratory Assistant in Financial University under the Government of the Russian Federation, Moscow, Russia. He is an author of 5 high-cited scientific publications indexed in SCOPUS. Main scientific interests are: energy, resource conservation, region, energy-efficient development, energy indicators, modeling, forecasting, strategic planning, alternative payment system, independence of network operation, limited emission, quantitative supply of bitcoins, crypto-mining complexity, network hashrate, bitcoin inflation, halving of remuneration.

ORCID ID: http://orcid.org/0000-0003-3995-4648

Kristina SHVANDAR is the Head of the Center for Advanced Financial Planning, Macroeconomic Analysis and Finance Statistics in Research Institute of Finance of the Ministry of Finance of the Russian Federation. She has Doctor of Economics of Lomonosov Moscow State University. She is author of more than 35 works, including 4 monographs. Research interests: analysis and forecast of the main trends of world economy, foreign sector of the Russian economy; analysis of the country's balance of payments; competitiveness of the national economy; macroeconomic forecasting; cashless payments \& national currencies.

ORCID ID: https://orcid.org/0000-0001-9946-5681

Oleg LITVISHKO is Associate Professor of the Department of Financial Management, a leading researcher at the Plekhanov Russian University of Economics, Moscow, Russia. He is the author of more than 50 scientific papers and conference materials indexed in Russian and international scientific databases (11 SCOPUS and WoS articles in total) on problems of Economics and Finance both at the macro level and at the level of individual industries and companies. As an author he has two monographies and one intellectual property patent. His main research interests are Economics in the field of sports, tourism, and a healthy lifestyle, as well as the development of digital technologies within the financial market.

ORCID ID: https://orcid.org/0000-0002-2722-5109

Valery TITOV is Doctor of Economics, Professor of Computer Science department at the Plekhanov Russian University of Economics, Moscow, Russia. He is the author of more than 110 scientific papers and conference materials indexed in Russian and international scientific databases (5 SCOPUS and WoS articles) on problems of economics and information technology in the educational process. He is the author of two monographs and co-author of three textbooks. The main area of scientific interest is the economy and application of innovative technologies in the educational process, development of a methodology for studying structural transformations in innovative systems. He is a corresponding member of the Russian Academy of Natural Sciences, editorial board member of a number of leading scientific journals of the Russian Federation. ORCID ID: https://orcid.org/0000-0001-7441-3180

Make your research more visible, join the Twitter account of ENTREPRENEURSHIP AND SUSTAINABILITY ISSUES: @Entrepr69728810

Copyright (C) 2020 by author(s) and VsI Entrepreneurship and Sustainability Center

This work is licensed under the Creative Commons Attribution International License (CC BY).

http://creativecommons.org/licenses/by/4.0/

CC) (i) Open Access 